\title{
MIDWIFE REGULATION, EDUCATION, AND PRACTICE IN THE NETHERLANDS DURING THE NINETEENTH CENTURY ${ }^{1}$
}

\author{
by \\ M. J. VAN LIEBURG and HILARY MARLAND *
}

\begin{abstract}
Although within The Netherlands, there is a growing interest in the history of midwifery and its practitioners, ${ }^{2}$ publications in languages other than Dutch have been few and far between. ${ }^{3}$ Consequently, little is known internationally about the development of midwifery and obstetrics in Holland. In stark contrast, in other European countries and, more particularly, America, there is a large literature on midwifery and obstetrics, including studies by feminist historians, sociologists, and historians of the professions, as well as medical historians. It seems paradoxical that the United States, one of the nations where the role of the midwife has declined most significantly in the twentieth century, has also produced the largest number of major studies on midwifery and its practitioners; ${ }^{4}$ The Netherlands, recognized as one of the few wealthy Western countries where midwives still play a major role in childbirth, has produced little historical analysis.
\end{abstract}

*Professor M. J. van Lieburg, MD, and Hilary Marland, Ph.D., Vakgroep Metamedica, Instituut Medische Geschiedenis, Vrije Universiteit, Van der Boechorststraat 7, 1081 BT Amsterdam, The Netherlands; and Instituut Medische Geschiedenis, Erasmus Universiteit Rotterdam, Postbus 1738, 3000 DR Rotterdam, The Netherlands.

1 This article is based on a paper presented at the conference 'Obstetric Problems, Past and Present', celebrating the fiftieth anniversary of the Nuffield Department of Obstetrics and Gynaecology, held in Oxford 10 October 1987. (Organized by the Wellcome Unit for the History of Medicine, Oxford, in association with the Nuffield Department of Obstetrics and Gynaecology.)

2 For example, J. J. Klinkert, Verloskundigen en artsen verleden en heden van enkele professionele beroepen in de gezondheidzorg, Alphen aan den Rijn and Brussels, Stafleu, 1980; E. Scholte, M. J. van Lieburg, and R. O. Aalbersberg, Rijkskweekschool voor Vroedvrouwen te Rotterdam, Leidschendam, Ministerie van Volksgezondheid en Milieuhygiene, 1982; Floor van Gelder, 'Is dat nu typies vrouwenwerk? De maatschappelijke positie van vroedvrouwen', Tijdschr. Vrouwenstud., 1982, 3: 5-33; H. M. Dupuis et al., Een kind onder het hart. Verloskunde, volksgeloof, gezin, seksualiteit en moraal vroeger en nu, Amsterdam, Amsterdams Historisch Museum and Meulenhoff Informatief, 1987; M. J. van Lieburg and Hilary Marland (eds.), Midwifery in the Dutch Republic, Amsterdam, Rodopi, [1990], a collection of Englishlanguage essays on midwifery during the seventeenth and eighteenth centuries.

${ }^{3}$ With the exception of the recent paper by Anja Hiddinga, 'Obstetrical research in The Netherlands in the nineteenth century', Med. Hist., 1987, 31: 281-305.

${ }^{4}$ Jane B. Donegan, Women and men midwives. Medicine, morality, and misogyny in early America, Westport, Conn., and London, Greenwood Press, 1978; Judy Barrett Litoff, American midwives 1860 to the present, Westport, Conn., and London, Greenwood Press, 1978; Richard W. and Dorothy C. Wertz, Lying-in. A history of childbirth in America, New York, Schocken, 1979; Catherine M. Scholten, Childbearing in American society, 1650-1850, ed. Lynne Withey, New York and London, New York University Press, 1985; Judith Walzer Leavitt, Brought to bed. Childbearing in America 1750 to 1950, New York and Oxford, Oxford University Press, 1986, and the essays in idem (ed.), Women and health in America, Madison, University of Wisconsin Press, 1984. 


\section{Midwife regulation, education, and practice in The Netherlands}

Present-day midwives in Holland hold a position of relative autonomy vis-à-vis obstetricians. They attend and supervise single-handedly such a large proportion of births, including many home deliveries, as to indicate that the specialty evolved in a way very different from many other European countries and America. In 1910, about $60 \%$ of all deliveries in The Netherlands were performed by midwives. This percentage gradually fell to $48 \%$ in $1940,41 \%$ in $1950,37 \%$ in 1960 , and $36.7 \%$ in 1970 . By 1977 there had been a small increase: out of 175,000 babies born, $37.8 \%$ were delivered by midwives (an average of 84 per midwife per annum, and a total of 66,000 deliveries). By 1983 the proportion of births attended by midwives had again risen. $57.7 \%$ of the 171,000 deliveries in Holland in 1983 were attended by doctors, and $41.6 \%$ by midwives. $^{5}$

In Holland, as elsewhere, the nineteenth century was a crucial period. In many countries this was an era of decline for the midwife, in terms of both status and the tasks she performed, in part due to pressure from male competitors. ${ }^{6}$ But in The Netherlands this was also, in a number of ways, a period of consolidation for the midwife. Early in the century, midwives were already included in legislation to control medical practice, and facilities were established for their training, examination, and regulation. As the century progressed, the tasks of the various professional groups, including the obstetric specialist and general practitioner, were clearly delineated, leaving !arge numbers of trained midwives opportunities to practise in an independent way. By the end of the century, midwives had set up their own professional organization and journal.

In the absence of accessible secondary literature, this article will outline the main developments in midwife practice and education during the nineteenth century. The term "midwife" will be applied here in its narrowest sense, referring to those receiving a school or apprenticeship training and a licence to practice. Those practising outside these boundaries, untrained or informally trained, unlicensed and unregulated, will not be considered, nor will the yet more informal childbirth assistance offered by female family members, friends, and neighbours. This is by no means to deny the significant role played by these informal practitioners, but merely to limit the scope of this survey. A thumbnail sketch will delineate the main legislative developments affecting the medical profession in general and midwives in particular during the nineteenth century. An outline will also be given of changes in the numbers of midwives and other obstetric practitioners during this period, of how midwives were selected, trained, and examined, their practices and incomes, and their relationship with male medical practitioners.

\footnotetext{
${ }^{5}$ I. Snapper, 'Midwifery, past and present', Bull. NY Acad. Med., 1963, 39: 526; Klinkert, op. cit., note 2 above, p. 72; Centraal bureau voor de statistiek, 1899-1979 Tachtig jaren statistiek in tijdreeksen, The Hague, Staatsuitgeverij, 1979, and Statistisch zakboek 1985, The Hague, CBS publikaties, 1985.

6 For England, Jean Donnison's study, Midwives and medical men. A history of inter-professional rivalries and women's rights, London, Heinemann, 1977, remains the standard on the changing relationship between male and female midwifery practitioners in the nineteenth century. For the United States, see especially Donegan, op. cit., note 4 above, and Litoff, op. cit., note 4 above; and, for the early twentieth century, Neal Devitt, 'The statistical case for elimination of the midwife: fact versus prejudice, 1890-1935', Women and Health, 1979, 4: 81-96, 169-86; Frances E. Korbin, 'The American midwife controversy: a crisis of professionalization', Bull. Hist. Med., 1966, 40: 350-63; Judy Barrett Litoff, The American midwife debate.
} 


\section{J. van Lieburg and Hilary Marland}

Primary sources for The Netherlands, particularly numerical evidence, are far richer than for nineteenth-century England or America, due to legislative developments and the introduction of regulation, and the early institutionalization of midwife training. ${ }^{7}$ For the period up to the late nineteenth century, largely unworked and unpublished statistical material, chiefly in the form of the provincial and state medical registers, has been drawn upon. Around the turn of the century, medical practitioners drew up a number of reports on midwife practice, and these, despite their built-in biases, have also been utilized in this analysis, particularly their numerical data.

THE ORGANIZATION OF THE MEDICAL PROFESSION IN HOLLAND AT THE BEGINNING OF THE NINETEENTH CENTURY

The first enactments to affect midwifery practice, as indeed, all medical practice, in The Netherlands were passed following the occupation of the country by the French in $1795 .^{8}$ After the conclusion of peace that year, the old Republic of the Seven United Netherlands was replaced by the legislatively active Batavian Republic. In 1798, eight ministries were set up, including a Ministry for National Education (Agentschap van Nationale Opvoeding), which implemented laws applying to the medical profession. In 1810, The Netherlands was absorbed into France, and for the next few years was directly under French legislative and executive control.

From 1798 onwards, the various groups practising medicine came to be regulated, including the non-academically-trained practitioners who played an important role in Dutch medical care for much of the nineteenth century. The institutions which had formerly regulated the medical profession, including the Collegia Medica, a municipal supervisory committee, consisting of a select group of physicians and surgeons, and the surgeons' guilds, made way for provincial (or departmental) committees, composed of the "most skilled and experienced men": medical doctors, surgeons, man-midwives, and pharmacists. The provincial committees were to maintain standards of medical practice, and to supervise the local committees which were to be established in districts with at least four practising doctors. ${ }^{9}$

Eighteen years of political subservience to France ended in 1813, and in 1818 an enactment re-organized the medical acts passed during the "French period". 10 The

A sourcebook on its modern origins, Westport, Conn., and London, Greenwood Press, 1986, and idem, 'Forgotten women: American midwives at the turn of the twentieth century', Historian, 1978, 40: $235-51$.

${ }^{7}$ For example, records are extant for the six clinical schools on midwife training, dating from 1824 until their closure in the $1860 \mathrm{~s}$; for the lying-in hospitals of several major towns from the early nineteenth century; and for the state schools for midwives in Amsterdam and Rotterdam from 1861 and 1882 respectively. The records of the provincial and state medical committees provide information on medical practice in nineteenth-century Holland; annual provincial and state medical registers list all officially recognized medical practitioners, including licensed midwives.

8 The most thorough guide in English to the political situation in The Netherlands during the nineteenth century is E. H. Kossmann, The Low Countries, 1780-1940, Oxford University Press, 1978.

${ }^{9}$ M. J. van Lieburg, 'De tweede geneeskundige stand (1818-1865). Een bijdrage tot de geschiedenis van het medisch beroep in Nederland', Tijdschr. Gesch., 1983, 96: 434.

${ }^{10}$ For a detailed account of Dutch medical legislation during the nineteenth century, see ibid., pp. 433-53. For a summary in English, see Hiddinga, op. cit., note 3 above, pp. 283-7. For a description of the Belgian medical profession during the nineteenth century, with its sometimes parallel development, see Rita Schepers, 'The legal and institutional development of the Belgian medical profession in the nineteenth century', Soc. Health and Illness, 1985, 7: 314-41. 


\section{Midwife regulation, education, and practice in The Netherlands}

new act, firstly, confirmed the precedence of national over local regulation and control, established during the French period. Secondly, the division within the medical profession between academic and non-academic practitioners, or university and non-university educated, was more clearly defined. The university-trained doctors were to receive a largely theoretical training, while the non-graduates were trained by apprenticeship. The two groups were separately licensed, medical doctors by the universities, and the non-academic group by the provincial committees. However, both groups fell under the control of the thirteen provincial medical committees. Thirdly, the spheres of practice of medical doctors, surgeons, and obstetric practitioners were defined, the law also differentiating between urban and rural medical practitioners.

The law of 1818 referred to three groups of obstetric practitioners: the doctor of obstetrics (who was also qualified as a medical doctor), the man-midwife, and the midwife. Instructions for each category of medical practitioner were drawn up, including special instructions for midwives. Obstetric doctors and man-midwives differed in their methods of training and examination. But, with respect to his practice, the obstetric doctor had to follow the instructions laid down for the man-midwife.

After 1818, the midwife continued to supervise most normal deliveries. According to the law of 1818 , a midwife had to be examined by a provincial committee before she could practise, and had to confine her practice to those births "which were natural processes or could be delivered manually, so that the midwife may never use any instruments for this purpose". She was, however, permitted to administer enemas and catheters. The midwife was instructed "to treat the woman gently and carefully", and to call in an obstetric doctor or man-midwife in difficult or dangerous cases; and she was obliged annually to report to the provincial committees on the complicated deliveries she had attended. The examination of the midwife concluded with the administration of an oath, in which she swore to maintain professional secrecy, and conduct all her affairs "as a good-natured and humane midwife was supposed to do". 11

As a result of the law of 1818 , fees for all categories of medical intervention were fixed by many of the provincial committees. Fees for obstetric cases varied between the three groups of obstetric practitioners. In South Holland, the fee for a normal delivery in large towns was fixed at a maximum of 63 guilders and a minimum of 6 guilders for man-midwives, and 25 and 3 guilders for midwives. In the countryside, the corresponding charges ranged from 30 to 3 guilders, and 15 to 2.10 guilders. Special tariffs were also fixed for the giving of enemas and introducing of catheters by midwives. ${ }^{12}$ While scales of charges were carefully detailed, little is known of the total incomes of midwives during this period. Those employed by the town councils as midwives to the poor were paid a fixed allowance of two to three hundred guilders per annum (about equivalent to the earnings of a labourer), but they were able to supplement this with fees from private practice.

11 Verzameling van wetten, besluiten en reglementen, betrekkelijk de burgerlijke geneeskundige dienst in het Koningrijk der Nederlanden, The Hague, J. P. Beekman, 1836, p. 197.

12 Ibid., pp. 150-3. 


\section{J. van Lieburg and Hilary Marland}

THE TRAINING OF MIDWIVES BEFORE 1860

According to the law of 1818 , midwives were to be trained by apprenticeship to a licensed midwife, but only after they had been educated for at least one year in the "theory of midwifery". The law referred implicitly here to the municipal courses in anatomy and obstetrics that had been given by medical doctors in the bigger Dutch towns since the end of the seventeenth century. The law also anticipated the setting up of special schools for the non-academic training of surgeons, man-midwives, pharmacists, and midwives. Before 1798, such training had been regulated by the surgeons' or pharmacists' guilds, but after this date no formal provision existed. A decree of 1823 , however, provided for the foundation of provincial or municipal schools in those towns where a hospital could facilitate clinical training. Between 1824 and 1828 six such "clinical schools" were established in Middelburg, Haarlem, Hoorn, Alkmaar, Amsterdam, and Rotterdam. The Amsterdam and Rotterdam schools, with the highest numbers of pupils, came to be the most important.

Admission to the schools was confined to women, aged between twenty and thirty, who were healthy and capable of carrying out the work of a midwife, literate, and of "irreproachable character". Some of the pupil midwives were sent by local authorities for a small fee of $\mathbf{2 0}$ guilders per annum; other were admitted on a private basis. The course, which lasted for two years, was both theoretical and practical, although only three hours per week were devoted to theory. During the remaining time, the pupil midwife accompanied a trained midwife to both hospital and domiciliary deliveries.

Table 1: NUMBERS OF PUPIL MIDWIVES ATTENDING THE CLINICAL SCHOOLS OF THE NETHERLANDS, 1824-67

$\begin{array}{lccccccc} & \text { A'dam } & \text { R'dam } & \text { Middelburg } & \text { Haarlem } & \text { Hoorn } & \text { Alkmaar } & \text { Total } \\ 1824-9 & 2 & 4 & 9 & 7 & 8 & 8 & 38 \\ 1830-9 & 28 & 29 & 13 & 3 & 24 & 24 & 121 \\ 1840-9 & 34 & 24 & 9 & 6 & 14 & 16 & 103 \\ 1850-9 & 45 & 20 & 11 & 7 & 15 & 3 & 101 \\ 1860-7 & 24 & 14 & 1 & 3 & 5 & 6 & 53^{*} \\ \text { Total } & 133 & 91 & 43 & 26 & 66 & 57 & 416\end{array}$

*The substantial decline in the number of pupils in the years $1860-7$ was due to the opening of the state school for midwives in Amsterdam in 1861, which was followed by the winding up of training for midwives in the clinical schools.

Source: M. J. van Lieburg, De studenten aan de geneeskundige scholen in Nederland (1824-1867). Een reconstructie van het Album Studiosorum, Amsterdam, Rodopi, 1989.

Table 1 shows the number of pupil midwives attending the six clinical schools of The Netherlands between 1824 and 1867 , broken down into ten-year periods. Of a total of 416 pupils admitted to the six schools, 321 (over $77 \%$ ) passed the final examination, and qualified as midwives. The number of school-trained midwives, however, remained low, especially when compared with the number licensed following a period of apprenticeship on a private basis with a trained midwife. Both paths led to examination by the provincial medical committees. Between 1824 and 1867 an average of only eight women graduated from the six clinical schools each year. By 1850 , as shown in table 2, there were 811 licensed midwives in The Netherlands, of whom fewer than a third had received training in the clinical schools. In the province of South 
Holland, fifty-nine trainee midwives were examined by the provincial medical committee between 1828 and 1841 . Of these, only nineteen $(32 \%)$ had graduated from the local clinical school in Rotterdam. ${ }^{13}$ There was a distinct contrast between school and non-school training for midwives, graduates from the schools receiving a more systematic and theoretical (but not necessarily more thorough or useful) education.

Table 2: NUMBERS OF LICENSED MIDWIVES IN THE NETHERLANDS DURING THE NINETEENTH CENTURY

\begin{tabular}{lllll} 
& Year & Midwives & Trained (\%) & \\
\cline { 3 - 4 } & & & Before 1865 & After 1865 \\
& 1820 & 819 & & \\
& 1830 & $820^{*}$ & & \\
1865 & 1840 & 811 & & \\
medical & 1850 & 811 & & \\
act & 1860 & 725 & $596(78)$ & $171(12)$ \\
& 1875 & 767 & $383(50)$ & $381(50)$ \\
& 1885 & 764 & $238(29)$ & $592(71)$ \\
& 1895 & 830 & - & -
\end{tabular}

*Estimate. Source: Provincial and state medical registers.

THE MEDICAL AND OBSTETRIC PROFESSIONS IN THE MID-NINETEENTH CENTURY

The position of midwives during the mid-nineteenth century should also be considered against the background of the general development of the medical profession in The Netherlands. 1838 marked an important turning point in intraprofessional relationships and the division of medical tasks. The ban on combined practice for medical doctors was then revoked, giving them the right to attend at obstetric cases, not only as consultants to man-midwives and midwives, but also as normal birth attendants. As a result, there was a massive increase in the number of medical doctors acquiring a second degree in obstetrics, as illustrated in table 3 . In 1820 , only $4.4 \%$ of medical doctors also held an obstetric degree; by 1866 this percentage had increased to $59.2 \% .{ }^{14}$ As a consequence, academic training in obstetrics became much extended. In Leiden, Abraham Simon Thomas (1820-86) was appointed Professor Extraordinary of obstetrics and gynaecology in $1848 ;{ }^{15}$ this was

\footnotetext{
13 D. J. A. Arntzenius, 'Statistieke opgaven omtrent de geneeskundige bevolking in Nederland', Bijdragen tot de Geneeskundige Staatsregeling, 1845, 3: 324.

14 Ibid.; state medical registers. Arntzenius took most of his data from the provincial medical registers. See also M. J. van Lieburg, 'De medische promoties aan de Nederlandse universiteiten (1815-1899)', Batavia Academica, 1987, 5: 1-17, for the overall number of doctorates conferred by Dutch universities.

${ }^{15}$ Simon Thomas was appointed to a full professorship in 1857, which he retained until his death in 1886. He also taught obstetrics to the Leiden midwives from 1863. See Hiddinga, op. cit., note 3 above, p. 292, and G. A. Lindeboom, Dutch medical biographies. A biographical dictionary of Dutch physicians and surgeons 1475-1975, Amsterdam, Rodopi, 1984, pp. 1815-16. For Simon Thomas and other eminent obstetric practitioners in the nineteenth century, see P. H. Simon Thomas, Het onderwijs in de verloskunde aan de Leidsche Hoogeschool gedurende het tijdvak 1791-1900, Leiden, S. C. van Doesburgh, 1909; G. C. Nijhoff, 'Bijdrage tot de geschiedenis der praktische verloskunde en gynaecologie in Nederland (18501860)', Ned. Tijdschr. Geneesk., 1907, 51, 1A: 36-47 and idem, 'Het onderwijs in de verloskunde en de uitoefening der verloskunst in Nederland gedurende de laatste 75 jaren', ibid., 1924, 68, IIA: 25-32; Hector
} 


\section{J. van Lieburg and Hilary Marland}

the first, and for sixteen years the only, chair of obstetrics and gynaecology in The Netherlands. At other universities, chairs of obstetrics and surgery were combined.

Table 3: NUMBERS OF MEDICAL PRACTITIONERS IN THE NETHERLANDS, 1820-95

$\begin{array}{rlrrlrrrr}\text { Date } & \text { Population } & \text { MD } & \text { OD } & \text { OD/MD \% } & \text { S } & \text { MM } & \text { GP } & \text { MW } \\ c .1820 & 2,109,069 & 637 & 28 & 4.4 & 1081 & 540 & - & 819 \\ c .1840 & 2,705,620 & 841 & 268 & 31.9 & 1453 & 1102 & - & 811 \\ 1855 & 3,183,003 & 1022 & 457 & 44.7 & 1422 & 1268 & - & 837 \\ 1866 & 3,444,328 & 990 & 586 & 59.2 & 1639 & 1302 & 8 & 692^{*} \\ 1875 & 3,769,111 & 875 & ? & ? & 1010 & ? & 132 & 767 \\ 1885 & 4,262,054 & 563 & ? & ? & 622 & ? & 556 & 764 \\ 1895 & 4,807,776 & 384 & ? & ? & 408 & ? & 1009 & 830\end{array}$

MD medical doctor (medicinae doctor)

OD obstetric doctor (obstetriae doctor)

$\mathrm{S}$ surgeon (heelmeester)

MM man-midwife (vroedmeester)

GP general practitioner of medicine (arts)

MW midwife (vroedvrouw)

*All medical personnel were instructed to re-register under the medical law of 1865 . The fact that many midwives chose not to re-register perhaps best explains the low figure for 1866.

Sources: Arntzenius, op. cit., note 13 above, pp. 25-53; provincial and state medical registers.

This development coincided with a debate on the unity of the medical profession, initiated by a group of young, progressive medical practitioners. As a prelude to new legislation, in 1849 the Dutch Society for the Promotion of Medicine (Nederlandsche Maatschappij tot Bevordering der Geneeskunst, NMG) was founded, the first national professional organization of doctors in Holland. ${ }^{16}$ The NMG's primary aim was to change the medical law of 1818 according to the ideal of a profession unified in terms of education and licensing. As a pressure group, it was far from representative. For many years dominated by medical doctors and town surgeons, it attracted little support from the countryside: $32 \%$ of the medical profession had joined by 1850 , and by 1865 this had only increased to $37 \%$. After 1876 the NMG's membership finally included more than

Treub, 'Verloskunde en gynaecologie in de laatste 50 jaaren', ibid., 1899, 35, II: 123-37; and for a more recent assessment, H. Beukers, 'De opkomst van het universitair onderwijs in verloskunde en gynaecologie in Nederland', in F. J. J. van Assen (ed.), Een eeuw vrouwenarts, Amsterdam, Rodopi, 1987, pp. 241-57.

${ }^{16}$ On medical societies before 1849 , see M. J. van Lieburg, 'Geneeskunde en medische professie in het genootschapswezen van Nederland in de eerste helft van de negentiende eeuw', De Negentiende Eeuw, 1983, 7: 123-45. For the period after 1849, see C. C. Delprat, 'Het ontstaan der Nederlandsche Maatschappij tot Bevordering der Geneeskunst en haar rol bij de herziening der geneeskundige staatsregeling van 1818', in Gedenkboek der Nederlandsche Maatschappij tot Bevordering der Geneeskunst, privately printed, 1924, pp. 19-109. The mid-nineteenth century also witnessed the establishment of a number of medical periodicals. In 1857 several of these amalgamated to become the Dutch Journal of Medicine (Nederlands Tijdschrift voor Geneeskunde), the organ of the NMG. For pre-1857 medical journals, see idem, 'De geschiedenis der Nederlandsche geneeskundige tijdschriften van 1680 tot 1857', Bijdr. Gesch. Geneesk., 1927, 7: 1-114, 201-314, 417-90. For medical journals in the period 1840-70, see M. J. van Lieburg, 'De Nederlandse medische tijdschriften en de wetenschappelijke geneeskunde 1840-1870', in D. de Moulin (ed.), Kracht en stof. De introductie van moderne natuurwetenschappelijke denkwijzen in de geneeskunde, zoals blijkt uit Nederlandse medische vakbladen, 1840-1870, Amsterdam, Rodopi, 1985, pp. 1-18. 


\section{Midwife regulation, education, and practice in The Netherlands}

half of the profession. ${ }^{17}$ However, pressure from the NMG did contribute towards the passing of the medical act of 1865 , which created a new category of medical practitioner, the arts (pl. artsen), who was permitted to practise internal medicine, surgery, and obstetrics. The necessity of providing training for this large new group of practitioners led to the establishment of academic hospitals, and to the appointment of professors in clinical subjects, including obstetrics, at all Dutch universities. ${ }^{18}$

Table 3 shows the changes in the numbers of each category of medical practitioner, including those involved in midwifery, before and after the medical law of 1865 . Through the century, man-midwives were forced to defend their positions vigorously in the face of growing numbers of academically-trained obstetric practitioners, both obstetric doctors and, after 1865, the artsen (general practitioners). The growth in the number of artsen resulted in increased competition between all categories of obstetric practitioners, and a further polarization between graduates and non-graduates. Meanwhile, elements in each category of male obstetric practitioner continued to depict midwives in largely negative terms.

\section{THE PRACTICE OF VROUW WALTMAN OF DORDRECHT}

The casebook of a mid-nineteenth-century midwife, Vrouw Waltman, ${ }^{19}$ who practised in the town of Dordrecht, ${ }^{20}$ just south of Rotterdam, offers some insight into a domiciliary midwifery practice of this period. Willemina Waltmen was born in 1802 into a working-class family, her father, Cornelis van Eysbergen, being a millwright in Dordrecht. Vrouw Waltman's education was confined to primary school attendance, a fact later reflected in her primitive handwriting and the simplicity of the casebook notes. In 1823, aged twenty-one, she married Dirk Waltman, a painter, and the son of a town beadle. Only nine years later, in 1832, she was left a widow with two young children to support. While far from well-off, Vrouw Waltman was apparently not left penniless, and nine years passed before she began to practice midwifery. She took her midwifery examination before the provincial medical committee in Dordrecht in 1841, at the age of thirty-nine. It is not known where or with whom she trained, although it is likely that she was apprenticed to a local midwife or man-midwife.

After passing the examination, Vrouw Waltman soon built up a busy practice. In 1842 she delivered twenty-nine women, and in the following year this figure had increased to sixty-seven. Five years later she was attending twice as many cases, delivering 140 women in 1847. The number continued to increase until her peak year, 1857, when she attended 268 deliveries, an average of five a week. In 1860 Waltman was appointed as town

\footnotetext{
17 Van Lieburg, op. cit., note 9 above, p. 448.

${ }^{18}$ Idem, 'Municipal hospitals and non-academic medical teaching in The Netherlands in the nineteenth century', Clio Medica, 1989, 21.

${ }^{19}$ A. C. Drogendijk, 'Het dagboek van Vrouw Waltman', Ned. Tijdschr. Geneesk., 1936, 80, I: 981-8.

20 For midwifery and childbirth in Dordrecht, see also idem, De verloskundige voorziening in Dordrecht van 1500 tot heden, Amsterdam, H. J. Paris, 1935. The 1930s saw the publication of a number of regional histories of midwifery practices and practitioners, infant and maternal mortality, and the folk traditions surrounding childbirth. For example, J. H. Hagenbeek, Het moederschap in Overijssel. Een onderzoek naar de verloskundige en de zuigelingenzorg in de provincie Overijssel, Zwolle, H. Tulp, 1936; P. E. G. van der Heijden, De zorg voor moeder en kind in Noord-Brabant, diss., University of Amsterdam, 1934; J. H. Starmans, Verloskunde en kindersterfte in Limburg. Folklore, geschiedenis, heden, Maastricht, Van Aelst, 1930.
} 


\section{J. van Lieburg and Hilary Marland}

midwife to Dordrecht. After 1865 the number of cases she attended began to decline, to 101 in 1868, thirty-one in 1870, and in 1872, four. In July, 1873 Vrouw Waltman attended at what was to be her last delivery, the birth of a grandson. She died the following year, aged seventy-two. ${ }^{21}$

Vrouw Waltman appears to have been highly respected in the community, and her services were much in demand. An official inquiry made during the mid-nineteenth century revealed that there were in practice in Dordrecht one doctor of obstetrics, twelve man-midwives, and ten midwives, so Vrouw Waltman had no lack of competition. Yet out of the eight or nine hundred births in Dordrecht annually, Vrouw Waltman attended many more than her quota, in some years around a quarter of all births; during her thirty years in practice she delivered almost 5,000 children. ${ }^{22}$ Vrouw Waltman's average fee per case was not high, approximately 2.50 guilders, but her annual income of up to five or six hundred guilders was respectable. ${ }^{23}$

In her casebook, Vrouw Waltman noted down whether deliveries were early or had gone to full term; the position of the child; if it had been necessary to call in a man-midwife or second midwife; whether the child was born alive or dead, or had died shortly after birth; details of the pregnancy and lying-in period; and any unusual occurrences during childbirth. Most deliveries were normal head presentations, but Waltman also recorded seven face presentations, thirty breech, eleven footling, and four knee presentations in her casebook. Thirty-six children presented in a transverse position; Vrouw Waltman included within this definition twenty arm and nine stomach presentations, and one back presentation. Of the fifty-three twins delivered by Waltman, twenty-nine presented abnormally. ${ }^{24}$ Even in difficult deliveries, Vrouw Waltman seldom found it necessary to call for assistance: during her entire career, she mentioned summoning a man-midwife or another midwife on only twenty-nine occasions each. Her casebook demonstrates that she was familiar with the technique of version and extraction. In one case, instruments had to be employed to complete the delivery; in another, the mother had an abnormally narrow pelvis. A case of placenta praevia was also mentioned in the casebook. In all of these deliveries Vrouw Waltman summoned a man-midwife to assist. To judge from the mortality rates of the children she delivered, Vrouw Waltman's results were good by nineteenth-century standards, although, as always, such results should be taken with more than a pinch of salt, for the death of infants was normally recorded only at birth or directly afterwards. While Vrouw Waltman delivered 205 stillborn children, only six were recorded as dying shortly after birth, giving a total perinatal mortality rate of $4.27 \% .^{25}$

\section{THE CONSEQUENCES OF THE LAWS OF 1860 AND 1865 FOR OBSTETRIC PRACTICE}

The law of 1865 instituted a system whereby admission to the medical profession could only be achieved through the passing of a state examination for artsen, composed of theoretical and clinical parts. This gave successful candidates the authority to practise all

\footnotetext{
${ }^{21}$ Drogendijk, op. cit., note 19 above, pp. $982,984$.

22 Ibid., pp. 982-3, 985.

23 Ibid., p. 984.

24 Ibid., p. 986.

25 Ibid., p. 987.
} 
branches of medicine. Although those already qualified as obstetric doctors could continue to practise midwifery after 1865 , the degree of obstetric doctor, still possible to acquire, became irrelevant. Likewise, those qualified as man-midwives could also continue to practise. However, the provincial medical committees ceased to function as examining bodies in 1865, and the qualification of man-midwife was abolished; consequently, the number of man-midwives declined. Meanwhile, as table 3 demonstrates, the number of artsen, in effect a new group of obstetric practitioners, grew almost eightfold, from 132 in 1875 to over 1,000 in $1895 .{ }^{26}$ The growth in the number of artsen was paralleled by a decline in the numbers of both medical doctors and pure surgeons after 1865 . The relative decline of midwife numbers in the middle of the nineteenth century is also illustrated in table 3 . In 1876 , new legislation made university education, including training in obstetrics, uniform and, in practice, compulsory for all medical practitioners. In 1885 the state and universities combined to set up a state medical examination.

Obstetrics and gynaecology were included in the general rise of specialties towards the end of the nineteenth century in The Netherlands. In 1887 the Dutch Association of Gynaecologists (Nederlandse Gynaecologische Vereniging, NGV) was founded by a small gathering of Amsterdam surgeons, who, in 1889, initiated the Dutch Journal of Gynaecology and Obstetrics (Nederlands Tijdschrift voor Verloskunde en Gynaecologie). Through their association and journal, this group promoted the recognition of obstetrics and gynaecology as a specialist subject and branch of practice. During the nineteenth century, this small collection of specialists tended not to come into conflict with general obstetric practitioners, including midwives, because they normally confined themselves to consulting practices.

As far as midwives were concerned, the law of 1865 merely confirmed an enactment of 1860 which had been motivated by the belief that, as one minister stated, the "class of midwives is, to the damage of society, sinking more and more in general esteem" ${ }^{27}$ The law of 1865 restated a clause of the act of 1818 , that midwives were "only to attend such deliveries, that were the work of nature, or which could be executed by hand" ${ }^{28}$ In some respects, this nineteenth-century legislation marked a step backwards from the former situation of the midwife, in which, despite the lack of organized, systematic training, she sometimes attended at complicated deliveries, and, more rarely, practised gynaecology and surgery. Vrouw Catharina Schrader, the widow of a provincial surgeon, who practised midwifery in Friesland in the north of Holland during the late seventeenth century and first half of the eighteenth, provides an outstanding example of a midwife who was able to acquire much experience and skill, partly through assisting her husband in his practice. Vrouw Schrader became a specialist in emergency deliveries, and there is evidence to suggest that she picked up some surgical knowledge from her husband, and

\footnotetext{
${ }^{26}$ By 1910 there were 925 midwives in The Netherlands; between 1910 and 1960 the number decreased to 850. Meanwhile, the number of doctors more than tripled during this period, from 4,000 to over 13,000 . By 1983 the total number of doctors had increased to 31,185 (one to every 463 inhabitants); midwives numbered 950 (1:15, 215). Snapper, op. cit., note 5 above, p. 527; Statistisch zakboek 1985, op. cit., note 5 above, p. 63.

${ }^{27}$ Scholte, Van Lieburg, and Aalbersberg, op. cit., note 2 above, pp. 35-6.

${ }^{28}$ Klinkert, op. cit., note 2 above, p. 40.
} 


\section{J. van Lieburg and Hilary Marland}

also had skills in nursing and the compounding and dispensing of medicines. ${ }^{29}$ The wife of Hendrik van Deventer (1651-1724), ${ }^{30}$ the famous Dutch obstetrician and author of midwifery texts, similarly acquired a knowledge of obstetrics, which she applied in her midwifery practice, from assisting her husband. This may well have been a two-way process as Van Deventer acquired from his wife more knowledge of normal childbirth than most male practitioners had. While these women were exceptional in terms of both their knowledge and specialized practices, before the nineteenth century the possibility existed, despite some restrictive local acts, of midwives going beyond attendance at normal deliveries.

The legislation of the nineteenth century, which applied to the whole of The Netherlands, thus forbade midwives from attending at abnormal deliveries. If complications arose during a birth, the midwife was to summon an obstetric or medical doctor, a man-midwife, or, after 1865, an arts. If there were none to be had in the neighbourhood, she was to call for the assistance of a second midwife. Clearly, in some situations a midwife, either unable or unwilling to ask for help, would have decided to continue with the delivery on her own, but the extent to which this took place is uncertain. A report on the status of midwives made in 1897 by the Dutch Society for the Promotion of Medicine, however, stated that, out of 196 midwives sampled, almost $80 \%$ called for assistance in good time. ${ }^{31}$ A similar report, drawn up in 1911, also gave a percentage of $80 \% .^{32}$

The law of 1860 , recognizing the shortage of well-trained, especially school-trained, midwives in the rural districts established a new training system through the founding, in 1861, of a state school for midwives (Rijkskweekschool voor Vroedvrouwen) in Amsterdam. ${ }^{33}$ Following the implementation of the medical law of 1865 , the clinical

\footnotetext{
${ }^{29}$ For Vrouw Schrader, see Hilary Marland, M. J. van Lieburg, and G. J. Kloosterman, “Mother and child were saved". The memoirs (1693-1740) of the Frisian midwife Catharina Schrader, Amsterdam, Rodopi, 1987, and, for a summary of her life and work, Simon Schama, The embarrassment of riches. An interpretation of Dutch culture in the Golden Age, London, William Collins, 1987, pp. 525-35. In Dutch, see also, the fuller transcription of Vrouw Schrader's notebook with introductory essays, M. J. van Lieburg (ed.), C. G. Schrader's memoryboeck van de vrouwens. Het notitieboek van een Friese vroedvrouw 1693-1745, with an obstetric commentary by G. J. Kloosterman, Amsterdam, Rodopi, 1984; B. W. Th. Nuyens, 'Het dagboek van Vrouw Schraders', Ned. Tijdschr. Geneesk., 1926, 70, II: 1790-1801; and for a commentary on the Dutch edition of the notebook, Willem Frijhoff, 'Vrouw Schrader's beroepsjournal: overwegingen bij een publikatie over arbeidspraktijk in het verleden', Tijdschr. Gesch. Geneesk. Natuurw. Wisk. Techn., 1985, 8: $27-38$.

${ }^{30}$ A. J. M. Lamers, Hendrik van Deventer medicinae doctor 1651-1724. Leven en werken, Assen, Van Gorcum, 1946.

31 'Dutch Society for the Promotion of Medicine. Report of the committee to investigate the means by which medical men can improve the standard and status of midwives in The Netherlands' ('Nederlandsche Maatschappij tot Bevordering der Geneeskunst. Rapport der commissie ter onderzoek naar de wijze waarop door geneeskundigen, verbetering gebracht kan worden in het gehalte en positie der vroedvrouwen in Nederland'), March 1897. In Ned. Tijdschr. Geneesk., 1897, 33, I; 610-28.

32 'Report of the commission selected by the Dutch Society for the Promotion of Medicine and the Dutch Association of Gynaecologists on midwifery practice in The Netherlands' ('Nederlandsche Maatschappij tot Bevordering der Geneeskunst. Rapport der commissie in zake het vroedvrouwenvraagstuk hier te lande, benoemd door het Hoofdbestuur der Nederlandsche Maatschappij tot Bevordering der Geneestkunst in samenwerking met het Bestuur der Nederlandsche Gynaecologische Vereeniging'), February 1911. In ibid., 1911, 55, IA (Supplement): 1105-32.

${ }^{33}$ On the Amsterdam school, see S. Sievertsen Buvig, Geschiedenis van de Rijks-Kweekschool voor Vroedvrouwen te Amsterdam, van 1861 tot 1921, Amsterdam, 1921; the essays in Bij het honderdjarig bestaan van de Kweekschool voor Vroedvrouwen te Amsterdam, reprinted from Tijdschr. soc. Geneesk., 1961, 39:
} 


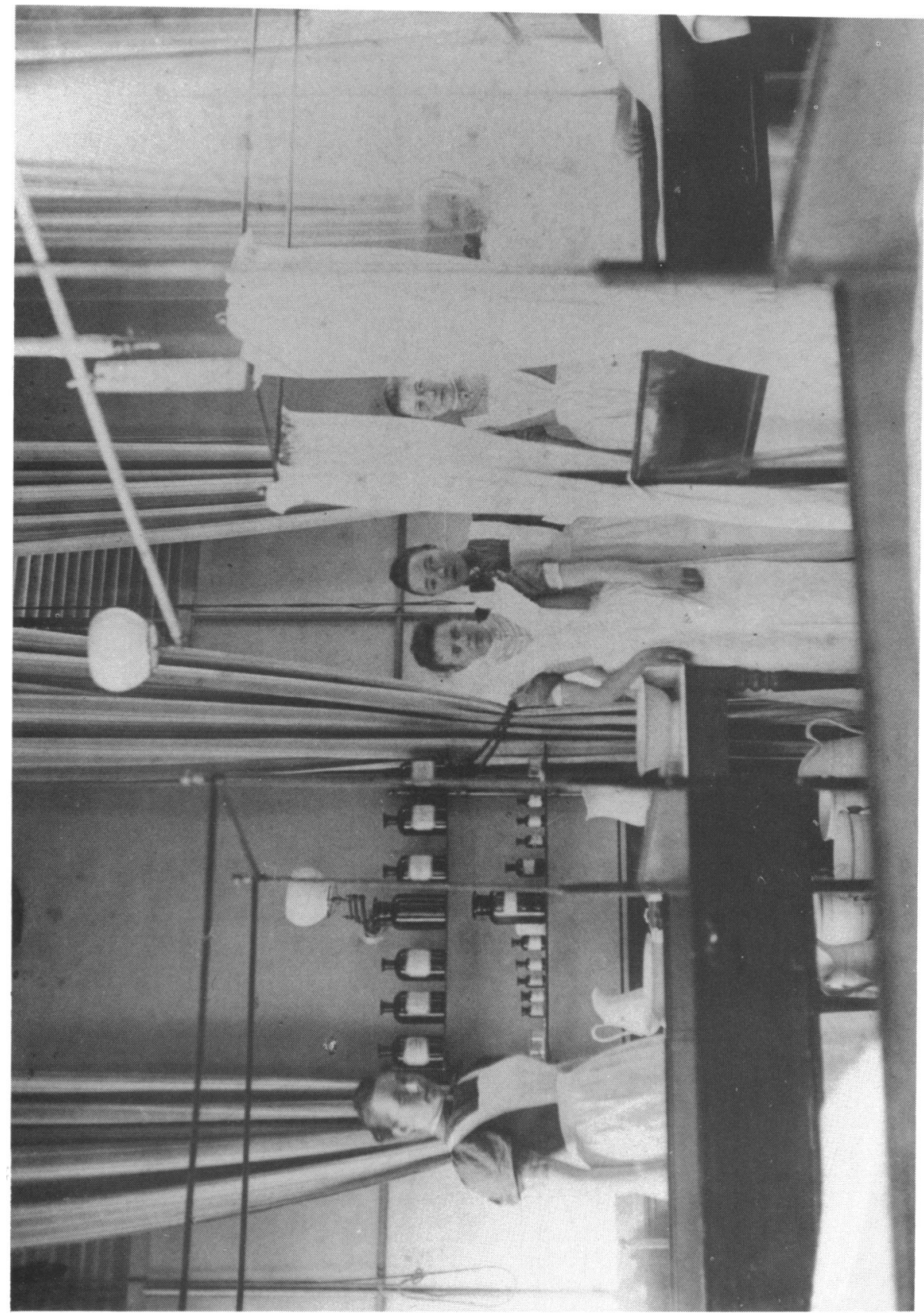

Plate 1. Nursing ward, c. 1890, in the state school for midwives in Rotterdam. 


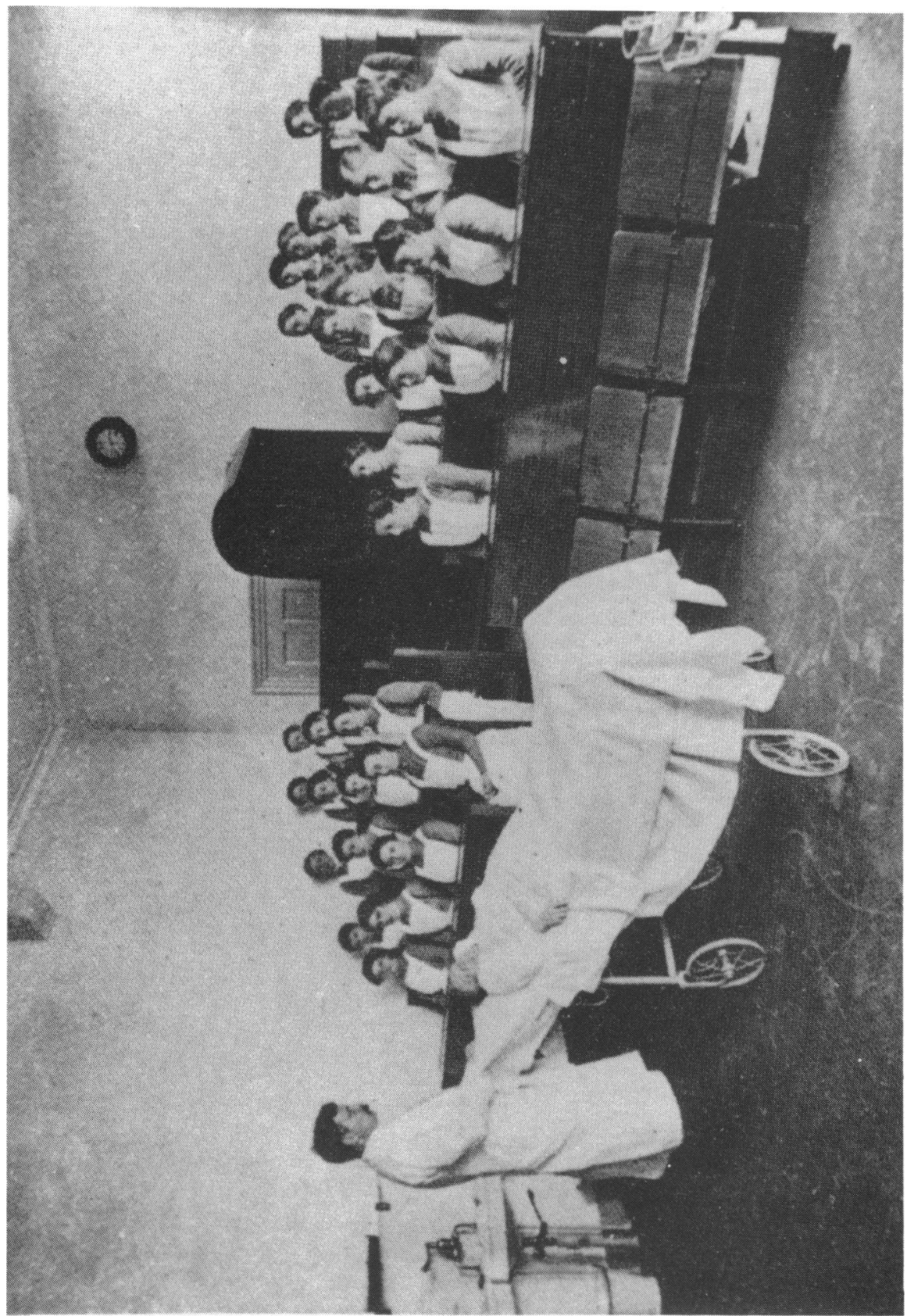

Plate 2. Clinical teaching in the state school for midwives in Rotterdam, c. 1912. K. de Snoo, the school's well-known medical director (1912-26), provides instruction. 


\section{Midwife regulation, education, and practice in The Netherlands}

schools were closed, except for the Amsterdam school, enabled to continue due to its special relationship with the Amsterdam Atheneum. ${ }^{34}$ The provincial medical committees were also dissolved, and a state commission took over responsibility for the examination of midwives. The sole alteration to the new state school system after 1865 was an expansion of the midwife training programme, through the establishment of a second school for midwives in Rotterdam in $1882 .{ }^{35}$ The municipal school of Groningen offered the only other institutional facility for training: since 1851 , midwives had been taught by the professor of obstetrics of the town's university. ${ }^{36}$

Training in the state schools for midwives was free, but the schools' graduates were obliged to practise for a number of years as midwife to the poor. There was a maximum number of pupils admitted each year: in Amsterdam twenty-six, and in Rotterdam thirty-two. Each Dutch province could send two women annually to train as midwives gratis; the selection of candidates rested with provincial inspectors of public health. Private pupils were also admitted. Those admitted to the course had to be aged between twenty and thirty-five, preferably unmarried women or widows, and as far as possible "respectable citizens, and gifted with such knowledge and reason needed for a thorough scientific training". ${ }^{37}$ The course lasted for two years, during which time pupils boarded in the schools, under the supervision of a "midwife-mistress". Training covered general anatomy and physiology, special knowledge of the female parts, the care of infants and sick women, and both theoretical and practical midwifery. Pupil midwives attended at deliveries in the associated clinics. Training in the state schools was recognized as being of a high standard, with a larger theoretical component than the clinical schools, but the general education of entrants was poor. To remedy this a teacher, who also functioned as matron and supervisor of the pupils, was appointed to teach the "three Rs". Finally, in 1902 an entrance examination was instituted.

Between 1861 and 1900 the total number of pupils trained at the Amsterdam state school was 1,143 (an average of 29 per annum); in Rotterdam, between 1882 and 1900, 628 (or 35 per annum). These figures represented a major increase on the numbers passing through the six clinical schools, which between 1824 and 1867 together trained only 416 women (approximately 10 per annum). However, while most of those trained in the clinical schools passed the final examination (almost $80 \%$ ), fewer than half of the women educated in the state schools graduated at the end of the course. Of the

609-50; J. Klomp, 'De "Camperstraat" verhuist-na 75 jaar. Ontwikkeling van de opleiding tot vroedvrouw in Amsterdam', Ons Amsterdam, 1976, 28: 2-11; H. J. Versteeg, 85 jaar Amsterdamse vrouwenkliniek, privately printed, with the support of the Stichting Wetenschapsfonds Verloskunde Gynaecologie A.M.C., Amsterdam, 1986.

34 After 1818, prospective doctors could train either for four years at an university or for two years each at an atheneum and university. The second option was far cheaper. There were four athenea in The Netherlands, at Harderwijk (1815-18), Franeker (1815-43), Deventer (1815-76), and Amsterdam (181577). In 1876 the status of the Amsterdam Atheneum was raised to that of town university.

35 On the Rotterdam school, see Scholte, Van Lieburg, and Aalbersberg, op. cit., note 2 above; M. J. van Lieburg, 'Uit de medische stadsgeschiedenis van Rotterdam: IV. Vroedvrouwen, verlosmeesters en doctoran', Monitor, 1975, 4: 77-80; K. de Snoo, De ontwikkeling van het vroedvrouwenonderwijs te Rotterdam, Rotterdam, W. L. en J. Brusse, 1914.

${ }^{36}$ On the Groningen school, see Catharine van Tussenbroek, De ontwikkeling der aseptische verloskunde in Nederland, Haarlem, De Erven F. Bohn, 1911, pp. 173-7.

${ }^{37}$ M. J. van Lieburg, 'De Rijkskweekschool voor Vroedvrouwen (1882-1926)', in Scholte, Van Lieburg, and Aalbersberg, op. cit., note 2 above, p. 55. 


\section{J. van Lieburg and Hilary Marland}

Amsterdam pupils admitted to the course, only $462(40 \%)$ passed the examination between 1861 and 1900. In Rotterdam the pass rate was similar, with 239 pupils (38\%) graduating between 1882 and 1900. In Amsterdam the failure rate in the examination itself was high; in Rotterdam there was a system of continuous assessment and poorer candidates were weeded out before they sat the examinations.

Table 4: PUPIL NUMBERS AT THE STATE SCHOOLS FOR MIDWIVES IN AMSTERDAM AND ROTTERDAM

\begin{tabular}{lllllllll}
\multicolumn{3}{l}{} & \multicolumn{7}{c}{ Amsterdam } & \multicolumn{2}{l}{ Rotterdam } \\
\cline { 2 - 9 } & $\begin{array}{l}\text { No. of } \\
\text { pupils }\end{array}$ & Examined & $\begin{array}{l}\text { Passed } \\
\text { exam }\end{array}$ & & $\begin{array}{l}\text { No. of } \\
\text { pupils }\end{array}$ & Examined & $\begin{array}{l}\text { Passed } \\
\text { exam }\end{array}$ \\
$1861-65$ & 107 & $?$ & 30 & $(-)$ & - & - & - & \\
$1865-70$ & 125 & $?$ & 62 & $(-)$ & - & - & - & \\
$1870-75$ & 129 & $?$ & 51 & $(-)$ & - & - & - & \\
$1875-80$ & 130 & 60 & 50 & $(83)$ & - & - & - & \\
$1880-85$ & 174 & 101 & 76 & $(75)$ & 89 & 20 & 19 & $(95)$ \\
$1885-90$ & 174 & 97 & 73 & $(75)$ & 176 & 84 & 66 & $(79)$ \\
$1890-95$ & 176 & 95 & 68 & $(72)$ & 177 & 75 & 75 & $(100)$ \\
$1895-1900$ & 128 & 62 & 52 & $(84)$ & 186 & 82 & 79 & $(96)$
\end{tabular}

Source: Van Tussenbroek, op. cit., note 36 above, pp. 150, 170.

The personalities and scientific background of the directors had a major impact upon the standard of education provided by the Amsterdam and Rotterdam schools. Perhaps the best example of this link is provided by Leopold Lehmann's directorship of the Amsterdam school, during the 1860 s and 1870s. Lehmann (1817-80), ${ }^{38}$ a dedicated follower of Virchow, had rejected the new theories of infectious diseases and bacteriology. Most significantly, he failed to recognize the link between puerperal fever and septic infection, and refused to introduce antiseptic techniques into the maternity ward. Complaints concerning the high mortality rate prompted the Amsterdam town council to appoint a committee to examine the maternity ward, but Lehmann died in 1880 before its report was completed. His successor, Professor G. H. van der Mey (1851-95), ${ }^{39}$ introduced antisepsis to the maternity ward, thus reducing the maternal mortality rate from around $4 \%$ to $0.88 \%{ }^{40}$ Lehmann's stand also brought him into conflict with the state examination committee, who refused to license many of the Amsterdam pupils. This helps account for the low number of midwives graduating from the Amsterdam school during the 1860s and 1870 s.

Table 5a shows the occupations of entrants to the Rotterdam state school between 1883 and 1909 . The most striking numbers are those for domestic servants, who made up around $20 \%$ of entrants, and the $57 \%$ with no occupation. Midwives in Holland during this period came largely from lower middle-class backgrounds, as can be seen from the small sample of the mothers of pupil midwives given in table $5 \mathrm{~b}$. There was little middleor upper-class input. Of the $\mathbf{4 3 2}$ cases where the occupation of the pupils' fathers is

${ }^{38}$ For Lehmann, see Lindeboom, op. cit., note 15 above, pp. 1165-6.

39 For Van der Mey, see ibid., pp. 1321-2.

${ }^{40}$ A. H. M. J. van Rooy, 'Drie kwart eeuw universitair verloskundig onderwijs te Amsterdam', in Gedenkboek uitgegeven ter gelegenheid van de viering van het vijf en zeventig-jarig bestaan van den Geneeskundigen Kring te Amsterdam, privately printed, 1923, pp. 105-6. 


\section{Midwife regulation, education, and practice in The Netherlands}

known, 63 (14.6\%) were farmers, 20 (4.6\%) shopkeepers, 16 (3.7\%) each were teachers, carpenters or tailors, $13(3 \%)$ each police constables or sailors, and $12(2.8 \%)$ shoemakers. Most of the rest were tradesmen, clerks, or minor civil servants. ${ }^{41}$

Table 5a: OCCUPATIONS OF PUPILS ADMITTED TO THE STATE SCHOOL FOR MIDWIVES IN ROTTERDAM, 1883-1909

Occupations

Children's nanny

Nurse (without diploma)

Nurse (with diploma)

Assistant teacher

Pupil teacher

Nursery school teacher

Dressmaker

Shop assistant

Clerk

Pharmacist's assistant

Handicraft teacher

No occupation
Domestic servant
Years

33

33
6

2

0

1

3

4

6

4

1

0

12

$67(52 \%) \quad 110(61 \%)$

$128 \quad 181$

\section{Total}

90

11

12

4

6

18

8

28

12

3

2

5

268

467

Total registering

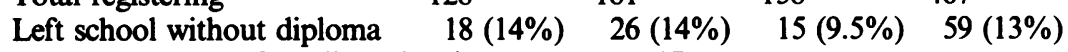

158

Left school without diploma $18(14 \%) \quad 26(14 \%) \quad 15(9.5 \%) \quad 59(13 \%)$
(\%)

Average number of pupils registering per annum 17

Source: 'Report', op. cit., note 32 above, p. 1117.

Table $5 b$ : OCCUPATIONS OF THE MOTHERS OF PUPILS ADMITTED TO THE STATE SCHOOL FOR MIDWIVES IN ROTTERDAM, 1883-1909*

$\begin{array}{lrll}\text { Dressmaker } & 4 & \text { Mangle woman } & 1 \\ \text { Midwife } & 27 & \text { Draper } & 1 \\ \text { Baker } & 2 & \text { Shopkeeper } & 2 \\ \text { Washerwoman } & 2 & \text { Landlady } & 2 \\ \text { Landlady of public house } & 1 & \text { Greengrocer } & 1\end{array}$

*Most pupils' mothers either had no occupation or the occupation was not recorded. Source: as for table 5a, p. 1119.

LATE NINETEENTH- AND EARLY TWENTIETH-CENTURY OBSTETRIC PRACTICE

While population ${ }^{42}$ and birth figures are readily available for the nineteenth century, there is little statistical information concerning obstetric attendance in The Netherlands during this period. The first reliable figures on obstetric attendance are for 1906, when just over 170,000 children were born in Holland. Of these, 61,000 , that is $36 \%$, were

\footnotetext{
41 'Report', op. cit., note 32 above, pp. 1118-19.

42 The population fluctuated around the two million mark between 1795 and 1815 , but from 1815 to 1830 it grew at an average annual rate of approximately 40,000 . Between 1850 and 1870 the population rose by almost $17 \%$ to reach $3,600,000$ in 1870 . By 1913 the population of The Netherlands had reached six million. Kossmann, op. cit., note 8 above, pp. 66, 215, 265, 419.
} 


\section{J. van Lieburg and Hilary Marland}

delivered by medical men, and 101,000 , or $59 \%$, by midwives. The remaining $5 \%$ were delivered without obstetric assistance. ${ }^{43}$ In 1910 there were almost 176,000 births, of which $58 \%$ were delivered by midwives, with an average of 110 attendances per midwife. ${ }^{44}$

In Holland, by the turn of the twentieth century, the urban/rural divide was still of little significance, with a low level of industrialization and few major cities, yet there were still noticeable regional differences in obstetric attendance. In the densely-populated and ubanized province of South Holland, out of a total of 41,500 births in 1906, 61.5\% were attended by midwives, and $38.2 \%$ by doctors. Meanwhile, in less populous North Holland, the proportions were $71.6 \%$ and $28.2 \%$ respectively, out of a total of almost 28,000 confinements. ${ }^{45}$

Figures are also available on the numbers of stillborn children delivered by midwives and doctors in 1906. Of the 61,000 children delivered under the direction of a medical man, just over 3,000 were born dead (5\%), compared with 1,775 out of the 101,000 children delivered by midwives (1.8\%). Some $255(2.9 \%)$ of the 8,712 children born without obstetric assistance were stillborn. In some regions the differences between the figures for midwives and medical men were more striking. In Limburg, for example, out of the total of 1,481 children delivered by medical men in 1906,173 or $11.7 \%$ were born dead; out of the 8,843 children delivered by midwives, 153 or $1.7 \%$. $^{46}$ Male obstetric practitioners were called in to attend at a higher proportion of pathological and protracted deliveries, and this goes a long way towards explaining the differences in the stillbirth rates. However, the regional variations need to be explained by other factors, be they economic, social, or related to the skills of the obstetric attendants. ${ }^{47}$

During the nineteenth century, as illustrated in table 2, the number of midwives in The Netherlands remained roughly constant, with a slight decline in the middle of the century. Their numbers, then, did not keep pace with the rise in population and births. Table 3 indicates that the total number of male obstetric practitioners also did not alter much during the century; and this suggests that numerical evidence is not the key to explaining changes in the division of labour. Rather, such changes can perhaps best be explained by alterations in the tasks, or in the size or duration, of the average midwifery practice. During this period, significant adjustments took place in the character of obstetric practices, including the medical man's takeover of much of the midwife's practice, and a likely increase in the average number of births attended by midwives.

\footnotetext{
43 Van Tussenbroek, op. cit., note 36 above, p. 183.

${ }^{44}$ Klinkert, op. cit., note 2 above, p. 72.

45 Van Tussenbroek, op. cit., note 36 above, p. 183.

46 Ibid., pp. 187, 189.

${ }^{47}$ Changes in maternal and infant mortality rates in Holland, and comparisons between the success rates of different groups of obstetric practitioners, and between The Netherlands and other countries, have been left out of consideration in this paper. For infant and maternal mortality, see, for example, ibid., and idem, 'Kraambedsterfte in Nederland', Ned. Tijdschr. Verlosk. Gynaec., 1912, 21: 1-37; the essays in Feestbundel opgedragen aan Hector Treub bij de feestelijke herdenking van zijn vijfentwintig-jarig professoraat, Leiden, S. C. van Doesburgh, 1912; James Young, 'Maternal mortality and maternal mortality rates', Am. J. Obst. \& Gynec., 1936, 31: 198-212, and Chr. Vandenbroeke et al., 'De zuigelingen- en kindersterfte in Belgie en Nederland in seculair perspectief', Tijdschr. Gesch., 1981, 94: 461-91. For comparisons of maternal mortality in various countries, including Holland, see Irvine Loudon, 'Maternal mortality: 1880-1950. Some regional and international comparisons', J. soc. Hist. Med., 1988, 1: 183-228.
} 


\section{Midwife regulation, education, and practice in The Netherlands}

As the male medical profession became increasingly overstocked during the mid- to late nineteenth century, midwives faced a growing tide of competition from, and, especially after 1865 , undercutting by, newly-qualified doctors intent on building up a general practice. Because the competence of midwives failed to be extended during the nineteenth century, it is possible that women turned more frequently to male obstetric practitioners to attend them in deliveries, rather than face the risk, having already paid for a midwife, of having to pay a second fee in the case of complications. As in other European countries and America, the "midwife question" came to the fore in Holland during the late nineteenth century. Dutch midwives were portrayed, both professionally and socially, in a negative light by many members of the medical profession during this period. A. Geyl (1853-1914), ${ }^{48}$ surgeon, gynaecologist, and medical historian, was one of the midwife's most formidable opponents. In a series of articles published in the Medical Weekly (Medisch Weekblad) in 1897 and 1911, ${ }^{49}$ Geyl concluded that seventeenth- and eighteenth-century midwives were, on the whole, unskilled, careless, and lacking in a sense of duty and professional integrity. By the nineteenth century their position had been much improved, but they were still, according to Geyl, inadequately trained and unfit for obstetric work. Midwives did, however, have patrons amongst the medical profession, including Meinart Niemeyer (1861-1934), ${ }^{50}$ a provincial general practitioner and medical journalist, and G. C. Nijhoff (1857-1932), ${ }^{51}$ professor of obstetrics and gynaecology, medical historian and a founder of the Dutch Association of Gynaecologists. Both men lent much support to late nineteenth-century midwife organizations and journals.

In 1897 the Dutch Society for the Promotion of Medicine drew up a report seeking ways to improve the position of midwives, through raising levels of practice, fees, and status. ${ }^{52}$ Although, one suspects, it reflects biases against midwives and their practices on the part of their male competitors, the report was fairly positive about the professional qualities of midwives; $60 \%$ of the medical practitioners responding to a questionnaire described the skills and theoretical knowledge of midwives as "good" or "very good". 53 The report also analysed the incomes of midwives. Generally, these were made up of payments by a town or region for attendance on the poor, which could take the form of a fixed payment or fee per case, and the fees of private patients, although occasionally medical men also paid midwives a fixed amount for attendance at deliveries.

The incomes of midwives, whatever their source, were subject to great variation. Before 1865 their fees were set in accordance with tariffs drawn up for all medical practitioners, guaranteeing some uniformity. After 1865 they fell outside of this scale of tariffs, and midwives in effect entered the "free market", which helps explain the growing variation in incomes. The fees paid to town midwives, for example, bore little relation to the number

${ }^{48}$ For Geyl, see Lindeboom, op. cit., note 15 above, pp. 674-5.

49 A. Geyl, 'Over de opleiding en maatschappelijke positie der vroedvrouwen in de $17 \mathrm{de}$ en 18de eeuw', Med. Weekbl'. 1897-8, 4: 6-10, 18-26, 35-41, 53-62, 67-73, 86-90, 115-17, and idem, 'Beschouwingen en mededeelingen over vroedvrouwen uit de 15de tot en met de 18de eeuw', ibid., 1911-12, 18: 227-31, 266-70, 279-83, 318-22, 341-5, 353-7, 368-9, 377-81, 401-6, 414-17, 425-30.

${ }^{50}$ For Niemeyer, see Lindeboom, op. cit., note 15 above, pp. 1419-20.

${ }^{51}$ For Nijhoff, see ibid., pp. 1427-8.

52 'Report', op. cit., note 31 above.

${ }^{53}$ Ibid., p. 612. 


\section{J. van Lieburg and Hilary Marland}

of deliveries attended, and ranged from the 150 guilders paid by the Amsterdam town council for attendance at more than one hundred deliveries per annum (less than 1.50 guilders per case), to the $\mathbf{4 0 0}$ guilders paid to the town midwife of 's Hertogenbosch in the east of The Netherlands, for an unknown, but presumably much smaller, number of deliveries. ${ }^{54}$ Private fees also varied greatly, according to the wealth of the town or region, and the availability of obstetric assistance. The report calculated that the fees paid by labourers and lower middle-class groups to midwives averaged 2.50 to 5 guilders, but the range could be much wider in either direction. In the province of North Holland the most usual fee was between 4 and 5 guilders for a normal delivery; in North Brabant 2.50 to 4 guilders was the average, but fees as low as half a guilder were also recorded. ${ }^{55}$ Yearly incomes were also subject to great variation. They could be less than three hundred guilders or more than eight hundred, but an average for the country as a whole was given as five to six hundred guilders per annum, ${ }^{56}$ an increase on the two to three hundred guilders cited in the early nineteenth century.

The report recommended that medical men offer more support to midwives and avoid direct competition with them, thus enabling them to extend their practices. In practical terms, little was achieved. One of the few concrete results of the report was the founding of a journal for midwives in 1897, the Journal of Practical Midwifery (Maandblad voor Praktische Verloskunde, and from 1899, Tijdschrift voor Praktische Verloskunde), by Niemeyer and Nijhoff, two members of the committee of inquiry, which came to cover medical issues, and information on the position of midwives in Holland and abroad. In the same year, the Dutch Society of Midwives (Bond van Nederlandse Vroedvrouwen) was founded; by 1898 it had around three hundred members. 57

The general lack of progress in improving the quality of midwives and their practices resulted in the compilation of another, substantially more detailed, report in 1911. This report also offers evidence about male medical practitioners' perceptions of midwives, including an analysis of the opinions of general practitioners on midwife practice. The main elements of the questionnaire are shown in table 6. About the midwives' knowledge and skills, the respondents were remarkably positive, much more so than in the 1897 report; more than $80 \%$ described the obstetric skills of midwives as "good" or "satisfactory". Almost $80 \%$ of the doctors participating in the survey believed that midwives called for assistance in difficult cases in good time; over $70 \%$ claimed that midwives were familiar with aseptic techniques. However, $61 \%$ of the respondents concluded that midwives did not conduct proper examinations of pregnant women, and $63 \%$ claimed that urine examinations were not made. While most of the

\footnotetext{
54 Ibid., p. 615.

55 Ibid., p. 616.

56 Ibid., p. 617. In general the salaries of nurses during this period were much lower. During the late nineteenth century nurses in the Buitengasthuis, Amsterdam were earning only 150 to 200 guilders per annum. Van Tussenbroek, op. cit., note 36 above, p. 94.

${ }^{57}$ Floor van Gelder, 'The case of the midwives, a forgotten profession. Social consciousness of working women in the Dutch public health care, 1900', unpublished paper presented at the Third Anglo-Dutch Labour History Conference, Maastricht, 1-3 April 1982, pp. 10-11. See also Van Gelder, op. cit., note 2 above.
} 
Midwife regulation, education, and practice in The Netherlands

respondents believed that a refresher course for midwives would be of value, $84 \%$ also believed that their competence should not be extended. ${ }^{58}$

Table 6: SUMMARY OF ANSWERS RECEIVED FROM GENERAL PRACTITIONERS CONCERNING THE PRACTICES OF MIDWIVES IN THE NETHERLANDS IN 1911

\begin{tabular}{|c|c|c|c|c|c|c|}
\hline \multirow{4}{*}{$\begin{array}{l}\text { General knowledge } \\
\text { Theoretical knowledge } \\
\text { Midwifery skills }\end{array}$} & \multirow{4}{*}{$\begin{array}{l}\text { Good } \\
59 \\
92 \\
197\end{array}$} & \multicolumn{2}{|c|}{ Satisfactory Moderate } & \multirow{2}{*}{$\begin{array}{l}\text { Bad } \\
84\end{array}$} & \multicolumn{2}{|c|}{ No answer } \\
\hline & & 178 & 112 & & 47 & + \\
\hline & & 214 & 61 & 66 & 47 & + \\
\hline & & 199 & 17 & 23 & 45 & + \\
\hline \multicolumn{7}{|l|}{ Practices of midwives- } \\
\hline Pregnancy examination & & 131 & 291 & & 58 & - \\
\hline Urine examination & & 141 & 303 & & 46 & - \\
\hline Correct diagnosis & & 377 & 64 & & 39 & + \\
\hline Calling timely assistance & & 380 & 70 & & 30 & + \\
\hline Supervision of nursing & & 216 & 218 & & 46 & $=$ \\
\hline Use of aseptic techniques & & 342 & 107 & & 31 & + \\
\hline Birth control advice & & $63^{*}$ & 381 & & 36 & - \\
\hline \multirow{2}{*}{\multicolumn{2}{|c|}{$\begin{array}{l}\text { Refresher course necessary } \\
\text { Extension of competence } \\
\text { recommended }\end{array}$}} & 291 & 103 & & 86 & - \\
\hline & & 53 & 402 & & 25 & - \\
\hline
\end{tabular}

*The low figure was largely due to a misunderstanding of the questionnaire on the part of the respondents, who equated birth control with assistance in abortions.

Number of doctors responding: 480.

Source: 'Report', op. cit., note 32 above, pp. 1130-1.

The character of obstetric practices in The Netherlands was very much related to the low level of institutional care for lying-in women, in either special or general hospitals. Until the beginning of the twentieth century, Dutch women regarded the lying-in hospital as the last resort, not least because of the poor conditions prevailing in these institutions (particularly in the Amsterdam clinic under Lehmann). There was a rigid division between home deliveries and hospital practice, which made no provision, as did British lying-in and general hospitals for example, for out-patient deliveries. The chief motive behind the establishment of lying-in hospitals in Holland was to provide facilities for clinical education. The Amsterdam lying-in hospital, a department within the general hospital, and the Rotterdam lying-in hospital (founded in 1831) were attached to the clinical and state schools, and were utilized in midwife training. By 1867 the Amsterdam lying-in clinic had over one hundred beds.

58 'Report', op. cit., note 32 above, pp. 1130-1. 


\section{J. van Lieburg and Hilary Marland}

However, generally, only a quarter of these were occupied by parturient women; the rest were taken up by sick children, patients suffering from eye diseases, and surgical cases. ${ }^{59}$ Leiden's university hospital was the first to establish lying-in facilities, following the appointment of Simon Thomas as professor in 1848 .

By the 1880s Holland still had only four lying-in clinics, connected to the universities of Amsterdam, Utrecht, Leiden, and Groningen. Together these catered for approximately 600 deliveries per annum, a number which rose to 850 between 1880 and the end of the century. ${ }^{60}$ The number of deliveries taking place within all institutions in Holland per annum around this time must have been well under a thousand. ${ }^{61}$ By the final decade of the nineteenth century, the Amsterdam clinic was dealing with approximately 450 to 550 deliveries each year, by far the highest number of institutional deliveries in Holland; ${ }^{62}$ midwife pupils at the Amsterdam school attended at well over one hundred deliveries per annum. ${ }^{63}$ The lack of institutional facilities in Holland ensured that most women, rich or poor, had their babies at home. It also limited the research possibilities of obstetricians, and meant that training facilities for medical students in midwifery remained inadequate. ${ }^{64}$ Institutional obstetrics in Holland only began to play a significant role after World War II, and as late as $1955,76.1 \%$ of deliveries took place at home. ${ }^{65}$

The practice of midwifery and obstetrics in The Netherlands incorporated a number of features which set it apart from other European countries and the United States. Perhaps the most striking divergences were the early introduction of legislative control and licensing for both male and female obstetric practitioners, the institutionalization of midwife training, and the very low incidence of hospital births.

There are obvious attractions in drawing up comparisons between the development of midwifery in Holland and other nations, in particular England and the United States, where the fortunes of midwives took very different, and well documented, turns in the late nineteenth and twentieth centuries. However, the problems of

59 A. W. C. Berns, De opheffing van de Amsterdamse kraaminrichting nader besproken, Amsterdam, 1881. Cited in Hiddinga, op. cit., note 3 above, p. 296.

60 Van Tussenbroek, op. cit., note 36 above, tables pp. 136, 86.

61 This compared dramatically with the situation in England, where, by the end of the nineteenth century, numerous lying-in and general hospitals and workhouses had made provision for the delivery of poor women, albeit not always on a large scale. In 1889, 2,234 in-patients and almost 25,000 out-patients were delivered in twenty-seven London medical charities alone. Between 1871 and 1880 an average of 2,300 women per annum were said to have been confined in thirty metropolitan Poor Law infirmaries. Report from the Select Committee on midwives' registration, PP, 1892, XIV (289), app. 4, p. 136.

62 Van Tussenbroek, op. cit., note 36 above, table p. 86.

63 Ibid., p. 170.

64 After the passing of the 1865 medical act, for example, facilities for the training of medical students were so inadequate in the university clinics that the university professors of Leiden, Utrecht, and Groningen had to arrange for the practical training of students by having them assist with home births under the supervision of midwives. Hiddinga, op. cit., note 3 above, p. 291.

65 In 1960 only $26 \%$ of the 242,407 deliveries in Holland took place in a hospital; the other $74 \%$ were home deliveries. Physicians conducted $63 \%$ of the total deliveries (152,753), $65 \%$ of them at home; midwives attended at $37 \%$ of deliveries $(89,504), 80 \%$ of them at home. Meanwhile, in the United States in 1957, $96 \%$ of deliveries took place in hospital. By 1965 the proportion of home deliveries in Holland had been reduced to $68.6 \%$, by $1975,44.4 \%$. In 1983 only $35.1 \%$ of babies in The Netherlands were born at home. Snapper, op. cit., note 5 above, p. 526; Klinkert, op. cit., note 2 above, p. 66; Statistisch zakboek 1985, op. cit., note 5 above, p. 52 . 


\section{Midwife regulation, education, and practice in The Netherlands}

drawing such comparisons are considerable. Holland differed enormously from other countries, not only in its institution of regulation, formal educational arrangements and licensing, but also in its arrangements for childbirth (the sketchiness of the institutional facilities for lying-in women has been described above), and in the way legislation was achieved (that is, it was initiated chiefly by the government, not the midwives, medical profession or other concerned pressure groups). It is difficult, given these factors, to find bases for comparison. In attempting to explain such differences, we are also drawn inevitably into an analysis of Dutch society and economy, educational provisions, population distribution and changes, the role of women in the work-force and professions, and the culture surrounding childbirth, a task which falls beyond the scope of this paper.

Only the simplest and briefest illustration of differences in midwifery practice in various European countries will be presented here, in the form of a table, reproduced largely from an article published by Dr S. Josephine Baker in 1912, which called for the better training and regulation of midwives in the United States. ${ }^{66}$ This table demonstrates the varying roles of midwives in providing childbirth attendance by the end of the nineteenth century, and perhaps also indicates the way the wind was blowing for the midwife in the countries represented.

Table 7: NUMBER OF MIDWIVES IN SELECTED EUROPEAN COUNTRIES IN THE LATE NINETEENTH AND EARLY TWENTIETH CENTURIES

\begin{tabular}{|c|c|c|c|c|}
\hline Country & $\begin{array}{l}\text { No. of } \\
\text { midwives }\end{array}$ & Year & $\begin{array}{l}\text { Midwives: } \\
10,000 \\
\text { inhabitants }\end{array}$ & $\begin{array}{l}\text { Births: } \\
\text { midwife p.a. } \\
\text { (average) }\end{array}$ \\
\hline Germany & 37,025 & 1898 & 6.8 & 55 \\
\hline Prussia & 20,878 & 1907 & 5.7 & 63 \\
\hline Austria & 20,000 & 1909 & 7.3 & 51 \\
\hline Switzerland & 3,305 & 1903 & 10.1 & 29 \\
\hline Norway & * & $*$ & 5.5 & 53 \\
\hline France & $*$ & * & 3.4 & 67 \\
\hline \multicolumn{5}{|l|}{ Italy } \\
\hline (active practice) & 15,000 & * & 4.3 & 81 \\
\hline Russia & 14,000 & * & 0.9 & $550 ?$ \\
\hline \multirow[t]{2}{*}{ England } & 12,500 & (est. 1892) & 2.6 & $36-52$ \\
\hline & 27,238 & (reg. 1909) & 7.3 & 38 \\
\hline \multirow[t]{3}{*}{ Netherlands** } & 830 & (lic. 1895) & 5.8 & unknown \\
\hline & 849 & (lic. 1905) & 6.5 & 119 \\
\hline & 924 & (lic. 1910) & 5.9 & 110 \\
\hline
\end{tabular}

*Data not supplied in Baker.

?This questionably high figure is taken from Baker.

**The figures for The Netherlands refer to trained and licensed midwives only.

Sources: Baker, op. cit., note 66 below, cited in Litoff, op. cit., note 6 above, p. 156; 'Report', op. cit., note 61 above, app. 6, p. 144; Klinkert, op. cit., note 2 above, p. 72; state medical registers.

${ }^{66}$ S. Josephine Baker, 'Schools for midwives', Am. J. Obst. \& Diseases of Women and Children, $1912,65$. Cited in Litoff, The American midwife debate, op. cit., note 6 above, p. 156. 


\section{J. van Lieburg and Hilary Marland}

At first glance, the midwife numbers for Holland seem low, but the 830 midwives trained and licensed in The Netherlands by the early $1890 \mathrm{~s}^{67}$ compare with 1,200 trained midwives in England, as estimated in the 1892 Parliamentary inquiry on midwife registration. ${ }^{68}$ In relation to the total population, there were approximately twice as many licensed midwives in Holland as all midwives in England. In terms of births attended, by 1910 each midwife in The Netherlands attended an average of 110 births per annum: ${ }^{69}$ in England, in 1909, the corresponding figure was a remarkably low 38 per annum. ${ }^{70}$

The scope of this paper has of necessity been confined to a discussion of regulated midwives. In Holland, as elsewhere, we are to a large extent prisoners of data which concentrate on trained and licensed midwives. Yet, in Holland, some women, often of the poorer classes, and almost certainly a much smaller number than in North America and other European nations, practised midwifery uncontrolled, often on an irregular basis, without formal education, but not necessarily without informal training or inexpertly. Midwives practising without a formal education and license, and thus in effect outside of the law, remain in just as much obscurity in Holland as in other countries, though the lack of concrete data on this group should not discourage some future analysis of their role in providing obstetric attendance and shaping childbirth practices. There is also an obvious necessity, again despite the difficulties of sources, for learning more about midwives' day-to-day lives and work. It seems likely, especially given her case load, that the Dutch midwife devoted less time to individual cases than her counterpart in other countries, confining her services to the delivery of the infant and post-natal check-ups.

Throughout the nineteenth century, Dutch midwives came largely from the lower middle- or artisan classes. The fees demanded by the midwifery schools, of 60 guilders for a two-year training course (roughly equivalent to one-tenth of a year's earnings in a good practice), ensured that the profession was accessible to members of lower social strata. ${ }^{71}$ Few middle- or upper-class women were attracted to midwifery in Holland during this period. This meant, on the one hand, that there was an absence of the tension which occurred, say, in England, between the "traditional" midwife, practising in her local community on an untrained and unlicensed basis, and the middle-class ladies, who from the late nineteenth century came to take advantage of the limited number of training courses in midwifery, and to dominate midwife societies and campaigns for legislation. On the other hand, the absence of a middle- or upper-class leadership group partly accounts, perhaps, for the comparative slowness of Dutch midwives in setting up midwifery societies and journals, and the domination of these organizations by male obstetric practitioners.

The low social status of midwives also served to isolate them from other female health professionals. The nursing profession, late to develop in Holland, tended,

${ }^{67}$ State medical registers, 1895.

68 'Report', op. cit., note 61 above, app. no. 6, pp. 144, 148.

${ }^{69}$ Klinkert, op. cit., note 2 above, p. 72.

${ }^{70}$ Baker, op. cit., note 66 above, p. 156.

71 This compared with the much larger fees demanded for English midwifery courses, charges which were prohibitive for many women. A short course in the prestigious London lying-in hospitals could cost as 


\section{Midwife regulation, education, and practice in The Netherlands}

unlike midwifery, to be dominated by women of high social status; their perception of nursing was shaped largely by religious and charitable impulses, not financial need or the desire for occupational satisfaction and mobility. ${ }^{72}$ The aims and practices of Dutch midwives had little in common with those of nurses; the two professions developed separately and remain distinct today. Meanwhile, women were slow to take up medical practice in Holland, the first female doctor, Aletta Jacobs, qualifying only in 1878; by 1900 only eleven women had qualified in medicine. ${ }^{73}$ Dutch midwives, also for social reasons, lacked the allegiance of aspiring female medical practitioners, often so important in other countries.

The story of Dutch midwives in the nineteenth century is one of pluses and minuses. Legislative developments laid the foundations for the future evolution of midwifery practice. It seems likely that without the early establishment of licensing, training facilities, codes of practice and divisions of labour, midwifery and the fortunes of midwives as a professional group would have taken very different courses. But midwives paid a price for this security, in the form of a more rigid definition of their roles in the delivery room. The legislation of 1818,1860 , and 1865 stated categorically that midwives were only to attend at normal deliveries: all difficult cases were to be turned over to or supervised by a male medical attendant. ${ }^{74}$

Encroachment upon midwife's practice by male obstetric practitioners, both obstetric specialists and general practitioners, was not eliminated by regulation. Nor did the reports drawn up around the turn of the century by male practitioners, with the intention of improving the status and practice opportunities of midwives, do much to reduce competition. Midwives in Holland fell increasingly under the control of male medical practitioners during the nineteenth century. The teaching of midwives in the clinical and state schools was undertaken largely by obstetricians; training was followed by examination by the medical men who made up the provincial and state medical committees. The domination of midwife organizations and journals by male obstetricians has already been referred to. The incomes of midwives, although apparently creeping up towards the end of the nineteenth century, remained significantly lower than those of male obstetric practitioners, even for attendance at normal deliveries. However, the early establishment of formal systems of training, examination and control in The Netherlands, while closely defining the sphere and practice limits of midwives, also enabled them to consolidate their positions as attendants in normal childbirth, and to operate with a higher level of autonomy than in many other countries.

much as $£ 30$ to $£ 40$ (equivalent to a year's earnings in a successful practice); even in workhouse infirmaries the fee for a three-month course could be $£ 10$. Donnison, op. cit., note 6 above, p. 59 .

${ }_{72}$ Cora Bakker-van der Kooy, 'Nurses and social consciousness', unpublished paper presented at the Third Anglo-Dutch Labour History Conference, Maastricht, 1-3 April 1982; Truus Spijker, Mooi en beschaafd verplegen. Een historische analyse van een vrouwenberoep, Lochem, De Tijdstroom, 1979.

${ }^{73}$ Hilary Marland, 'Women doctors in The Netherlands 1878-1920', unpublished paper presented at the Deutsch-Niederlandisches Medizinhistorikertreffen, Amersfoort, 11 June 1988; Mineke Bosch, 'Blauwkousen en hobbezakken in een witte jas: De eerste vrouwelijke artsen in Nederland, 1872-1913', in Josine Blok et al. (eds.), Jaarboek voor vrouwengeschiedenis 1982, Nijmegen, SUN, 1982, pp. 63-97.

${ }^{74}$ See especially the articles by Van Gelder, op. cit., notes 2 and 57, on the cutting back of the midwife's role in the nineteenth century. 